\title{
Analysis of the Maintain of Bali Traditional Games Through Photos and Videos of Games to Improve Digital Literacy
}

\author{
Made Agus Dharmadi ${ }^{1, *}$ A.A.N. Yudha Martin Mahardika ${ }^{2}$ \\ ${ }^{1}$ Sports Coaching Education Study Program, Universitas Pendidikan Ganesha, Singarja, Indonesia \\ ${ }^{2}$ Hospitality Study Program, Universitas Pendidikan Ganesha, Singarja, Indonesia \\ "Corresponding author. Email: agus.dharmadi@undiksha.ac.id
}

\begin{abstract}
This research is a follow-up study on the development of a website about traditional Balinese games in the previous year, because the website developed did not fully contain the types of games and game media in the form of photos and videos. This website will contain information and traditional Balinese games by searching documents about traditional games in Bali which are then integrated into the form of text, images and videos that will be published on the website. Data collection techniques used are literature study and documentation studies, interviews (FGD), and questionnaires (questionnaires). The activity plan adopts a system development life cycle consisting of planning, analysis, design, implementation (build and coding), testing and maintenance. Based on this, it can be concluded that photo and video media on websites about traditional Balinese games are very much needed (95\%) considering that there is no single website that can display traditional Balinese games as a whole, and also in the midst of declining interest in reading through books and developments. increasingly modern technology in the era of industry 4.0. This research is expected to be useful for educators, education and sports offices, and the department of education and culture as well as the wider community in the form of the availability of traditional Balinese games in the form of websites equipped with photos and videos, making it easier to understand, apply, educate, socialize traditions, and develop them. in the form of policy programs for the preservation of arts and culture/traditions, especially traditional Balinese games.
\end{abstract}

Keywords: Digital Literacy, Photo and video media, Traditional Games.

\section{INTRODUCTION}

Bali has a variety of cultures and traditional games from different regions and currently nationally, traditional games are thought to have been abandoned or even extinct. In Bali, traditional games must have started to fade, so efforts to preserve this culture from the onslaught of globalization have become a necessity. Traditional games are games that have existed for a long time, but these games are almost forgotten by the community, especially children. Children often play modern games using gadgets/smartphones rather than traditional games. Some of the reasons that may make modern games more popular than traditional games, among others, are because modern games have more variety, and have their own prestige value in the eyes of their friends.

In the midst of the era of globalization, it will be able to spur the exchange of information without limits so that it has an impact on the dissemination of cultural and traditional influences and values that can bring changes to people's patterns of thinking and acting, especially people among the younger generation who tend to be easily influenced by values. and inappropriate foreign culture. For this reason, efforts and strategies are needed that are appropriate and in accordance with developments in growing the strength of tradition and culture in accordance with the character of the nation. The development of science and technology, especially 
communication technology, has enabled people to communicate globally without being limited by space and time. The rapid development of information and communication technology has brought major changes in various sectors of life and has an impact on shifting mindsets, values and life behaviors, including the relationship between emotional experiences [1]. The rapid flow of exchange and dissemination of information through cyberspace (internet) has had an impact on people's behavior, so that in the current era the internet is a primary need today.

Although traditional sports games have been presented as one of the materials in learning physical education at every school level in the Education Unit Level Curriculum (KTSP) or the 2013 curriculum from elementary/middle school to high school/MA level, reading interest and interest in traditional game activities children are still very small, especially due to the low reading culture, the limitations of traditional game books at school and in bookstores, so that the public/children are more interested in reading through more modern media such as smartphones, tablets, laptops and so on. On the other hand, the teacher's role has actually been very helpful in its function of collecting and securing traditional Balinese games through physical education learning in schools.

The paradigm shift in people's reading from textbooks to smartphone/tab/laptop media has been very clearly seen, if we go to a crowded place, such as parks, malls, restaurants, even in schools and other places, the view that can be seen is how the community/children Children carry/play their smartphone/tab/laptop instead of carrying books or the like. The fact that digitalization technology has a crucial role in human life and even all mankind, digital games have significantly gained worldwide recognition that digital games are currently needed [2].

Research conducted by researchers in the previous year 2020 has succeeded in developing the existence of a website related to traditional Balinese games with the address www.permainantradisonalbali.com, which contains related traditional games in Bali, namely 9 districts in Bali. On the website, various explanations related to traditional Balinese games have been displayed. Of the dozens of traditional games in Bali, the traditional Balinese game website has listed all game models in all districts which were obtained based on the sources obtained. For now, for people who want to know the types of games, the history of the game, the rules of the game, to how the game is carried out, it has been provided on the website.

Currently in 2021, researchers want to improve the website with development research by making videos of traditional games in Bali, so that the explanations that have been narrated on the website can be better understood by the public with the presentation of video games. So the difference in the previous year's research lies in the type of development, where in 2020, the research was conducted by developing a website about traditional Balinese games containing materials for traditional Balinese games, while this year's research 2021 is directed at developing photos and videos of traditional Balinese games. so that the materials for traditional Balinese games become clearer, more complete and make it easier for the public to understand and understand how traditional Balinese games are played. Here's a look at the website that was successfully developed in the previous year 2020, still using the photos in the source book, so it looks like it's still black and white, and there's no video game yet. Therefore, to bring the website to life with actual color photos and videos, this follow-up research is important.

Seeing the importance of developing these photos and videos and the description of the large number of website visitors, this follow-up study, entitled Maintaining Culture and Traditional Balinese Game Traditions through Digital Photo and Video Literacy in the Industrial Era 4.0, is urgent.

\section{METHOD}

This research is development research, so this research design is a development design according to [3], which is modified with a system development life cycle so that the stages consist of 1) planning, 2) analysis, 3) design, 4) implementation (build and coding, 5) testing and 6) maintenance. Data collection activities using techniques according to the type of instrument used are as follows: 1) Participatory observation, carried out by researchers as observers by involving themselves in activities that are being carried out or are being experienced by users / organizers of traditional games, 2) Documentation studies, used to collect data in written documents/written literature that shows a relationship with the existence of photos and videos of traditional games. 3) Interview, used to interview a number of key informants who are considered to be key figures in the research, which can be in the form of Focus Group Discussions or in-depth discussions with internet users. 4) Questionnaires, used to obtain and collect a number of knowledges, understanding and implementation of all research samples in their activities towards the development of photos and videos of traditional Balinese games. In making the design of photos and videos of traditional Balinese games using a qualitative approach technique, because the research subjects and informants selected were not based on considerations of the quality of the information in the information provided but more concerned with the adequacy of the information needed. So that the analysis is carried out on existing traditional game documents, to then be analyzed in a qualitative description of the game material to be developed into 
material that is ready to be used on the traditional game website to be developed.

\section{RESULT AND DISCUSSION}

\subsection{Description of the Need for Photos and Videos of Traditional Balinese Games}

To find out the description of the need for photo and video media related to traditional Balinese games, it was done by distributing questionnaires to junior high, high school and college students in Bali. The number of respondents who filled out a questionnaire related to the analysis of the need for photo and video media in traditional Balinese games was 232 people. The results of the questionnaire can be explained as follows figure 1.

Based on Figure 1, that the public in obtaining information related to traditional Balinese games is 45.7\% through peers, $15.5 \%$ through books, $14.2 \%$ through Youtube, $12.9 \%$ through others.

Based on Figure 2, it was found that the existing Balinese traditional game books have shown pictures and video games with $65.1 \%$ stating that they already contain photo and video media, and 34.9 have not displayed photos and video games.

Based on Figure 3, it was found that in order to maintain the sustainability of traditional Balinese games, it is necessary to hold activities in the form of a traditional Balinese game festival as much as $37.1 \%$, holding competitions as much as $36.6 \%$, teaching students through sports learning in schools as much as $22 \%$.

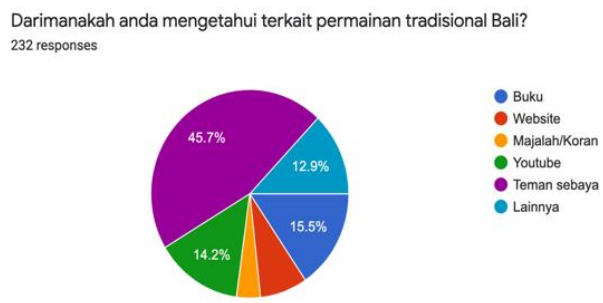

Figure 1 Information on public knowledge of traditional Balinese games

Apakah materi permainan tradisinal Bali yang anda ketahui melalui buku misalnya sudah menampilkan media gambar dan media video yang baik? 232 responses

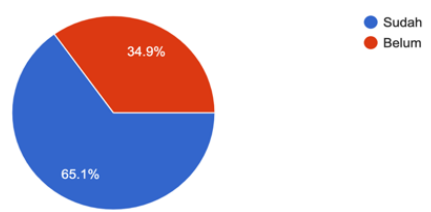

Figure 2 The existence of image media and video media in traditional Balinese game books
Menurut anda, dalam rangka melestarikan permainan tradisional kegiatan apa yang perlu dilakukan?
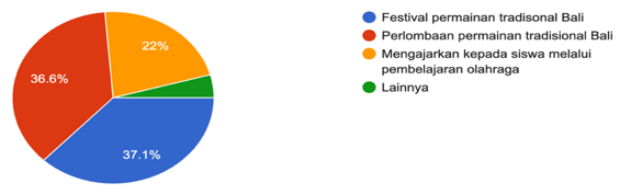

Figure 3 Activities that need to be done in preserving traditional Balinese games

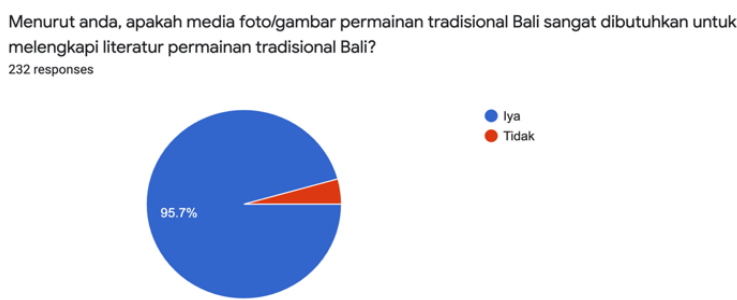

Figure 4 Completeness of traditional Balinese game literature

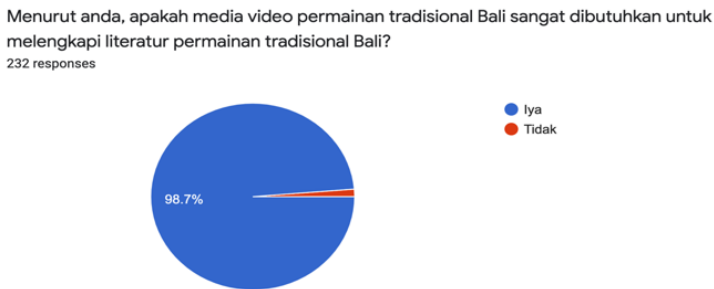

Figure 5 the need for video game media to complement traditional Balinese game literature

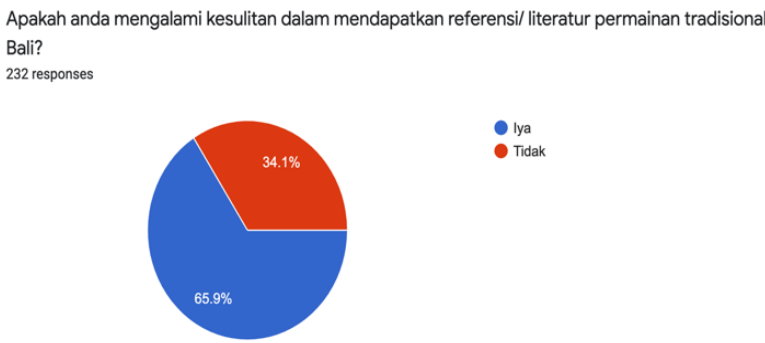

Figure 6 difficulty in getting references to traditional Balinese games

Based on figure 4 to figure 6 show that literatures to traditional games are hard to find and that video and photos of traditional games are needed to preserve the games. It would also be helpful as references. 


\subsection{Product Forms Photos And Videos About Traditional Balinese Games That Are Attractive, Informative And Interactive.}

In making photos and videos, the steps taken are as follows:

1. Planning and forming a team of photo and video creators

2. Selecting and sorting traditional Balinese games on the website www.gamenantradionalbali.com

3. Set a schedule for making photos and videos

4. Make photos and videos

5. Photo and video editing

6. Input photos and videos into the website

\section{CONCLUSION}

Based on the results obtained, it can be concluded that the making of photos on the website www.permainantradionalbali.com can be done with photos that are possible to do during the Pandemic and have been inputted on the website so that they can be enjoyed by the community by visiting the website address in browsing searches. which is on the internet. Based on this, it can be concluded that photo and video media on websites about traditional Balinese games are very much needed $(95 \%)$ considering that there is no single website that can display traditional Balinese games as a whole, and also in the midst of declining interest in reading through books and developments. increasingly modern technology in the industrial era 4.0. This research is expected to be useful for educators, education and sports offices, and the department of education and culture as well as the wider community in the form of the availability of traditional Balinese games in the form of websites equipped with photos and videos, making it easier to understand, apply, educate, socialize traditions, and develop them. in the form of policy programs for the preservation of arts and culture/traditions, especially traditional Balinese games.

\section{REFFERENCES}

[1] P. Lavega, "Relationship Between Traditional Games and the Intensity of Emotions Experienced,” J. Res. Q. Exerc. Sport, vol. 85, no. 457-467, 2014.

[2] I. .Hilvoorde, "Sport and Play in A Digital World," J. Sport. Ethics Philos., vol. 2, no. 1, pp. 325-345, 2016.

[3] Gall and Gall, Educational Research An Intruduction. Seven Edition. United State: Pearson education,

Inc.,

2003. 